RESEARCH PAPER RP1237

Part of Journal of Research of the National Bureau of Standards, Volume 23, September 1939

\title{
EFFECTS OF HUMIDITY AND COMPOSITION ON STRENGTH AND YOUNG'S MODULUS OF ENAMELS
}

\author{
By Dwight G. Moore and William N. Harrison
}

\section{ABSTRACT}

Both Young's modulus and the modulus of rupture of eight types of enamel frit were determined under constant conditions of temperature and humidity, by transverse loading of annealed fibers about three-fourths millimeter in diameter. Also, one enamel fired on metal specimens was tested under varying conditions of humidity for resistance to chipping in torsion. Fibers of two of the frits were tested in air under different humidities at constant temperature, immersed in different liquids at constant temperature, and immersed in water-free kerosene at different temperatures. The most noteworthy effect observed was that of humidity upon the modulus of rupture of the frit fibers and also upon the resistance of enameled-iron specimens to chipping in torsion.

\section{CONTENTS}

Page

II. Preparation of specimens.

III. Modulus of rupture tests_...

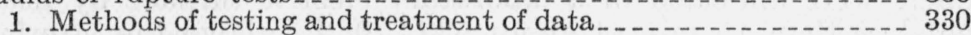

(a) Sustained-load tests

(b) Tests with uniformly increasing load

2. Effect of humidity on modulus of rupture

(a) Effect of humidity in sustained-load tests $\ldots \ldots \ldots . . . .332$

(b) Effect of humidity in tests with uniformly increasing load _... 333

3. Effect of immersion in different liquids on modulus of rupture .. 333

4. Effect of temperature on modulus of rupture

5 . Variation in modulus of rupture with type of frit......... 335

6. Discussion of results

IV. Torsion tests on enameled-iron specimens

1. Method of testing _........... 338

2. Effect of humidity on resistance to chipping by torsion $\ldots \ldots \ldots 38$

3. Discussion of results

V. Modulus of elasticity tests

1. Method of testing and treatment of data

2. Effect of humidity on modulus of elasticity

3. Variation in Young's modulus with type of frit_.......... 341

4. Discussion of results _...

VI. Conclusions_._.

VII. References_....... 343

\section{INTRODUCTION}

This report is the third in a series concerning the various properties of eight typical commercial enamel frits. The papers already published relate to consistency $[1]^{1}$ and surface tension [2]. A study of the thermal expansion and refractoriness of these enamels has been

\footnotetext{
1 Figures in brackets indicate the literature references at the end of this paper.
} 
completed but is not yet published. Both the method of selection and the composition of the frits have been previously reported [1]. The types of enamel represented are as follows:

Frit 1, a "soft" sheet-iron ground-coat frit, to be mixed with a harder frit before use.

Frit 11, a "hard" sheet-iron ground-coat frit, used with admixture of a softer frit.

Frit 6 , an acid-resisting type of white cover-coat frit for sheet iron.

Frit 25, an "ordinary" white cover-coat frit for sheet iron.

Frit 35, a "super-opaque" white cover-coat frit for sheet iron.

Frit 65 , a leadless dry-process frit for cast iron.

Frit 72, a high-lead (40 percent of $\mathrm{PbO}$ ) wet-process frit for cast iron.

Frit 85, a lead-bearing (10 percent of $\mathrm{PbO}$ ) dry-process frit for a cast iron.

\section{PREPARATION OF SPECIMENS}

The specimens used for both strength and elasticity determinations were drawn by hand as fibers from molten frit contained in platinum. The fibers were started with a round nickel rod, the temperature during drawing being adjusted to give fibers between 0.65 and $0.85 \mathrm{~mm}$ in diameter. Such specimens were chosen as approximating in thickness the enamel on normally coated ware. The length of the specimens for the modulus-of-elasticity tests was about $12 \mathrm{~cm}$ and for the strength tests about $4 \mathrm{~cm}$. Only straight fibers which were either of round cross section or but slightly out-of-round were chosen. These fibers were annealed in a laboratory electric furnace by heating for not less than $15 \mathrm{~min}$ at about $5^{\circ} \mathrm{C}\left(9^{\circ} \mathrm{F}\right)$ above the interferometer softening point [3] and cooling at a rate of approximately $2^{\circ} \mathrm{C}\left(4^{\circ} \mathrm{F}\right)$ per minute through the critical range.

Frit 6 was applied as an enamel coating on blanks of 20-gage iron, $8 \mathrm{in}$. $(20 \mathrm{~cm})$ long and $2 \mathrm{in}$. $(5 \mathrm{~cm})$ wide, which had been bent, before enameling, to form 1 -in. $(2.5 \mathrm{~cm})$ angle-iron specimens having a $1 / 16-i n$. $(2 \mathrm{~mm})$ radius of curvature (outside) at the apex. Each specimen was first ground-coated and then coated with enamel 6 on the outer surface. Before firing, the dried cover coat was brushed off a distance of $1 / 4$-in. $(6 \mathrm{~mm})$ from the edges and 2 in. $(5 \mathrm{~cm})$ from the ends of the specimen.

\section{MODULUS OF RUPTURE TESTS}

\section{METHODS OF TESTING AND TREATMENT OF DATA}

One of the more important variables in strength tests on brittle materials is the rate at which load is applied. The strength of glass, for example, has been shown to vary widely with the loading rate [4]. It, therefore, seems necessary either to control the loading rate closely or to eliminate this variable as far as possible by the use of sustained loads. In this investigation both methods were used.

(a) SUSTAINED-LOAD TESTS

The procedure used in the sustained-load tests, which has been previously described [5], may be easily understood by reference to 
figure 1. Using a $2.35-\mathrm{cm}$ span, 20 specimens were tested independently at each specified stress, never less than 5 separate stresses (100 specimens) being used for each determination. Each of the first set of 20 specimens was calipered and loaded at the center to give a maximum fiber stress of $8 \mathrm{~kg} / \mathrm{mm}^{2}$. After a lapse of $20 \mathrm{hr}$, two specimens, or 10 percent of the set, had failed. Twenty new specimens were then similarly tested at $9 \mathrm{~kg} / \mathrm{mm}^{2}$ and 20 percent of these failed. This procedure was repeated with stress increments of $1 \mathrm{~kg} / \mathrm{mm}^{2}$ until at least 80 percent of the specimens failed (95 percent in fig. 1). The median stress, that is, the stress required to break 50 percent of the specimens (approximately $11.5 \mathrm{~kg} / \mathrm{mm}^{2}$ in fig. 1), and the statistical error of the determination were computed from the data by the method of C. I. Bliss [6]. Throughout the investigation, the statistical 95 -percent-confidence error was used $[7,8]$.

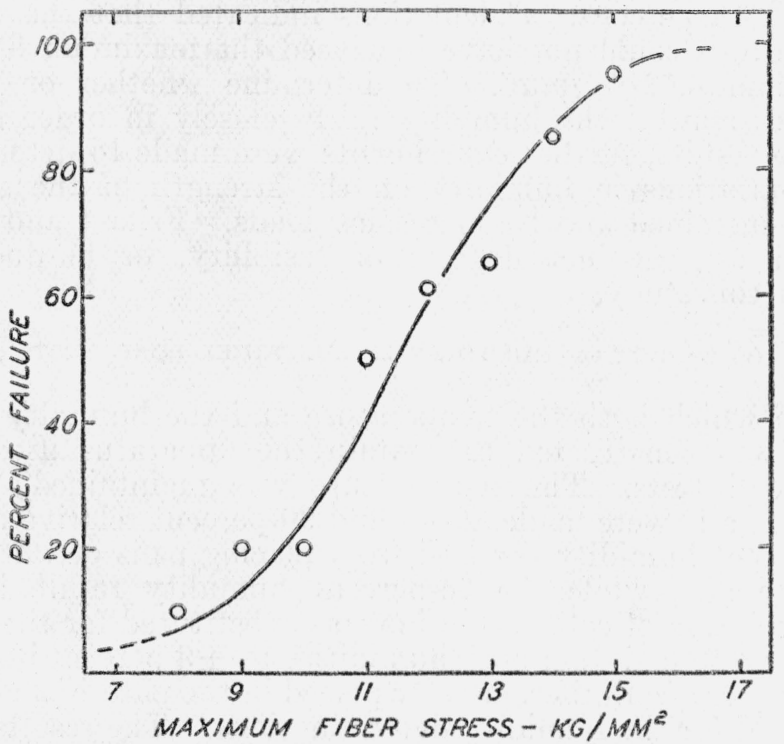

FIGURe 1.-Typical data obtained in a determination of modulus of rupture by sustained loading.

Each point indicates the percentage of a 20 -specimen sample which failed within 20 hours under sustained load at the indicated stress. The computed stress required for 50 percent failure was reported.

\section{(b) TESTS WITH UNIFORMLY INCREASING LOAD}

In the tests with uniformly increasing load, the stress was applied at the center of the specimen on a span of $2.35 \mathrm{~cm}$. The center knifeedge was attached to the base of a modified pan balance and remained stationary. The two end supports were suspended from one arm of the balance, and moved upward as the load was applied to the opposite arm by allowing water to run into a vessel supported therefrom. The water in the reservoir was kept at a constant head by use of a Mariotte bottle and hence flowed at a constant rate. This rate was $1.354 \pm$ $0.003 \mathrm{~g} / \mathrm{sec}$, and the applied loads were obtained to an accuracy of \pm 1 percent by means of a stop watch. In these tests the rate of stress 
application varied from a minimum of $0.132\left(\mathrm{~kg} / \mathrm{mm}^{2}\right) / \mathrm{sec}$ to a maximum of $0.295\left(\mathrm{~kg} / \mathrm{mm}^{2}\right) / \mathrm{sec}$, depending on the diameter of the specimens. Twenty-five to fifty specimens were tested in each determination, and the statistical error was computed by ordinary methods [7].

\section{EFFECT OF HUMIDITY ON MODULUS OF RUPTURE}

In a period of relatively high humidity, frit 85 gave 50 percent failures under sustained loading at a stress of $9 \mathrm{~kg} / \mathrm{mm}^{2}$. Later, under the same conditions, except for lower humidity, this same frit gave only 15 percent failures. However, when a small drop of water was placed gently on the midpoint of each specimen, the 17 test rods remaining unbroken out of the original 20 began breaking almost immediately and within 40 min showed 65 percent failures instead of the original 15 percent. Calculations indicated that the weight of the water drops could not have increased the maximum fiber stress by more than $0.03 \mathrm{~kg} / \mathrm{mm}^{2}$. To determine whether or not it is necessary to control the humidity fairly closely in order to obtain comparable results, further experiments were made to determine the effect of variations in humidity on the strength of the specimens broken by sustained and by increasing loads. Frits 1 and 6 , which represented two distinct degrees of fusibility, or hardness, were selected for this study.

\section{(a) EFFECT OF HUMIDITY IN SUSTAINED-LOAD TESTS}

A box in which both the temperature and the humidity could be controlled was constructed to contain the apparatus used for the sustained-load tests. The temperature was maintained at $36^{\circ} \mathrm{C}$ $\left(97^{\circ} \mathrm{F}\right)$ and tests were made at 56 - and 90 -percent relative humidity. The 90-percent humidity resulted from placing pans of water on the floor of the box, while the 56-percent humidity resulted when a saturated solution of cobalt chloride was substituted for the water, it being possible to maintain both humidities to \pm 3 percent in this way. A wet- and a dry-bulb thermometer placed in the path of a circulating fan were used for the humidity determinations. The results given in table 1 show significantly greater strength ${ }^{2}$ at 56 - than at 90-percent relative humidity. Frit 1 had the lower modulus of rupture and showed a greater effect resulting from humidity change, the strength being about 53 percent greater at the lower humidity. The strength of frit 6 was about 15 percent greater at 56 - than at 90 -percent relative humidity.

2 A difference was considered significant if there was a 95-percent or greater probability that it was not caused by chance fluctuations in sampling or in test conditions. To determine whether or not this requirement was fulfilled, the following ratio was used:

$$
\frac{d}{\sqrt{e_{1}^{2}+e_{2}^{2}}}
$$

In this ratio, $e_{1}$ and $e_{2}$ are the 95 -percent-confidence errors of two determinations, as computed by the method of Bliss (see reference [6]), and $d$ is the difference between the two determinations. If this ratio equaled or exceeded unity, the difference was considered significant, on a basis of 95-percent confidence. 
TABLE 1.-Modulus of rupture of fibers of frits 1 and 6 by sustained-load and by increasing-load tests

\begin{tabular}{|c|c|c|c|c|}
\hline Test method & $\begin{array}{c}\text { Frit } \\
\text { number }\end{array}$ & $\begin{array}{l}\text { Relative } \\
\text { humidity }\end{array}$ & $\begin{array}{l}\text { Number of } \\
\text { specimens }\end{array}$ & $\begin{array}{l}\text { Modulus of } \\
\text { rupture a }\end{array}$ \\
\hline Twenty-hour sustained loading at $36^{\circ} \mathrm{O}\left(97^{\circ} \mathrm{F}\right)$ & $\begin{array}{l}1 \\
1 \\
6 \\
6\end{array}$ & $\begin{array}{r}\text { Percent } \\
90 \\
56 \\
90 \\
56\end{array}$ & $\begin{array}{l}100 \\
100 \\
100 \\
100\end{array}$ & $\begin{array}{r}\mathrm{kg} / \mathrm{mm}^{2} \\
4.7 \pm 0.8 \\
7.2 \pm 0.6 \\
8.4 \pm 0.7 \\
9.7 \pm 0.6\end{array}$ \\
\hline Uniformly increasing load at $21^{\circ} \mathrm{C}\left(70^{\circ} \mathrm{F}\right) \ldots$ & $\begin{array}{l}1 \\
1 \\
1 \\
6 \\
6 \\
6\end{array}$ & $\begin{array}{l}98 \\
65 \\
35 \\
98 \\
65 \\
\mathbf{3 5}\end{array}$ & $\begin{array}{l}52 \\
51 \\
52 \\
52 \\
52 \\
52\end{array}$ & $\begin{array}{l}17.6 \pm 0.9 \\
18.0 \pm 1.5 \\
19.0 \pm 0.8 \\
22.2 \pm 1.3 \\
24.8 \pm 1.6 \\
27.2 \pm 1.9\end{array}$ \\
\hline
\end{tabular}

s Limits given are for 95 -percent confidence. See references $[6,7,8]$.

\section{(b) EFFECT OF HUMIDITY IN TESTS WITH UNIFORMLY INCREASING LOAD}

To study the effect of humidity on strength as determined by the increasing-load tests, frits 1 and 6 were tested in constant-temperature, constant-humidity rooms. The three rooms available for this purpose were held at $21^{\circ} \pm 0.5^{\circ} \mathrm{C}\left(70^{\circ} \pm 1^{\circ} \mathrm{F}\right)$, the relative humidities being 35,65 , and 98 percent (in each case \pm 2 percent), respectively. The specimens were stored in the rooms for not less than $20 \mathrm{hr}$ before testing. Table 1 includes a summary of the results of these tests, the trend of the data being shown graphically in figure 2. With both frits, the difference in strength, when tested at 35- and at 98-percent relative humidity, is definitely significant. ${ }^{3}$ Computations indicate about 97-percent confidence that the variation in strength with humidity is real for frit 1 , and well over 99-percent confidence for frit 6 . The strengths are, respectively, about 8 and 22 percent greater at 35 - than at 98 -percent relative humidity.

The two curves in figure 2 show definitely the downward trend of modulus of rupture as the relative humidity is increased. These curves are drawn as straight lines merely to show the trend, as the data do not necessarily establish a straight-line relationship.

\section{EFFECT OF IMMERSION IN DIFFERENT LIQUIDS ON MODULUS OF RUPTURE}

Since variations in atmospheric humidity affected the modulus of rupture, tests were made to determine the effect of immersion in various liquids, such as water, ethyl alcohol, and kerosene. For these tests, the increasing-load apparatus was modified slightly so that the specimens could be completely immersed in liquid during testing. In one experiment, specimens dried at $110^{\circ} \mathrm{C}$ were given a very thin moisture-repellent coating by dipping in molten paraffin before the test.

The results of these experiments are given in table 2. For some tests not all of the desirable information concerning storage conditions is available. The information gained from these tests was considered adequate, however, for the purposes of this investigation. Frit 1,

\footnotetext{
8 For these data, Fisher's " $t$ test" was used to determine the significance of differences (see reference [8]). This treatment of data is preferred by the authors but was not used for the sustained-load test, because data of that type are not susceptible of such treatment.
} 
when dried over $\mathrm{CaCl}_{2}$ and tested under kerosene containing sodium to eliminate water (test 4), was about 30 percent stronger than when tested under water after storage in open air (test 1). When tested in air and in alcohol after storage in open air (tests 2 and 3 ), the strengths were practically equal and were intermediate between those obtained under the first-mentioned conditions. This intermediate strength is significantly lower than that for dry specimens in kerosene but not significantly higher than that for specimens tested under

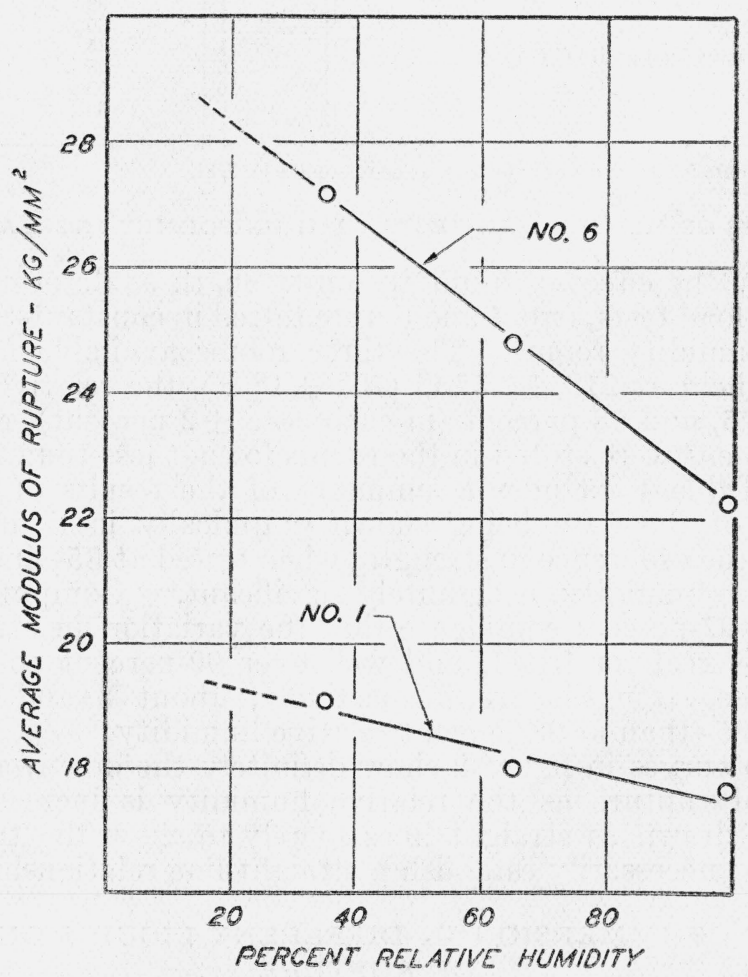

FIGURE 2.--Graph showing trend towards increasing modulus of rupture with decreasing relative humidity for fibers of frit 6 and frit 1 , when tested at $21^{\circ} \mathrm{C}\left(70^{\circ}\right.$ F') under uniformly increasing load.

water. Comparable conditions of storage and test for frit 6 (tests 5 , 6,7 , and 8 ) showed the same trend of results but more positively, the two intermediate values being significantly different from both extremes.

The strength of the dried specimens of frit 6 under kerosene was about 49 percent greater than that of the specimens tested under water, as compared with 30 percent for frit 1 . The strength of specimens of frit 6 tested in air at 65-percent relative humidity (test 6) was not significantly different from that of specimens stored at "room humidity" prior to testing under alcohol (test 7$)^{4}$ nor from

- Weather Bureau reports indicate that the atmospheric humidity at the time of the latter test was in or near the 60 - to 65 -pereent range. 
that of specimens stored in air at 60-percent relative humidity prior to testing in kerosene (test 9). Drying the specimens at $110^{\circ} \mathrm{C}$ $\left(230^{\circ} \mathrm{F}\right)$ prior to testing in kerosene (test 10$)$ gave nearly the same results as drying them over $\mathrm{CaCl}_{2}$ (test 8).

TABLE 2.-Modulus of rupture of frits 1 and 6 when stored under various conditions and tested in different media and at different temperatures, under constantly increasing load

\begin{tabular}{|c|c|c|c|c|c|c|c|}
\hline \multirow{4}{*}{$\begin{array}{r}\text { Test } \\
\text { num- } \\
\text { ber }\end{array}$} & \multirow{3}{*}{$\begin{array}{c}\text { Frit } \\
\text { num- } \\
\text { ber } \\
1\end{array}$} & \multirow{3}{*}{$\begin{array}{c}\text { Storage conditions prior to testing } \\
\text { Room temperature and humidity......... }\end{array}$} & \multirow{4}{*}{$\begin{array}{l}\begin{array}{l}\text { Surrounding me- } \\
\text { dium during test }\end{array} \\
\text { Water }\end{array}$} & \multicolumn{2}{|c|}{$\begin{array}{l}\text { Tempers- } \\
\text { ture of sur- } \\
\text { rounding } \\
\text { medium }\end{array}$} & \multirow{4}{*}{$\begin{array}{l}\text { Num- } \\
\text { ber of } \\
\text { speci- } \\
\text { mens }\end{array}$} & \multirow{4}{*}{$\begin{array}{c}\begin{array}{c}\text { Modulus } \\
\text { of rup- } \\
\text { ture }\end{array} \\
\mathrm{kg} / \mathrm{mm}^{2} \\
17.0 \pm 1.0 \\
18.0 \pm 1.5\end{array}$} \\
\hline & & & & ${ }^{\circ} \mathrm{C}$ & ${ }^{\circ} \mathrm{F}$ & & \\
\hline & & & & 26 & 79 & & \\
\hline & 1 & $\begin{array}{l}\text { 65-percent relative humidity, room temp- } \\
\text { erature. }\end{array}$ & & 21 & 70 & & \\
\hline 3 & 1 & Room temperature and humidity........ & Alcohol b.......... & 22 & 72 & 51 & $18.4 \pm 1.4$ \\
\hline 4 & $\hat{1}$ & $\begin{array}{l}\text { Dried over } \mathrm{CaCl} \text { for } 36 \text { hours at } 26^{\circ} \mathrm{C} \\
\left(79^{\circ} \mathrm{F}\right) \text {. }\end{array}$ & Kerosene & 27 & 81 & 31 & $22.1 \pm 1.8$ \\
\hline 5 & 6 & Room temperature and humidity........ & Water... & 21 & 70 & 52 & $19.2 \pm 1.4$ \\
\hline 6 & 6 & $\begin{array}{l}65 \text {-percent relative humidity, room temp- } \\
\text { perature. }\end{array}$ & Air & 21 & 70 & 52 & $24.8 \pm 1.6$ \\
\hline 7 & 6 & Room temperature snd humidty........ & Alcohol b. & 24 & 75 & 52 & $24.3 \pm 1.8$ \\
\hline 8 & 6 & $\begin{array}{l}\text { Dried over CaCl } \mathrm{Cl}_{3} \text { for } 36 \text { hours at } 26^{\circ} \mathrm{C} \\
\left(79^{\circ} \mathrm{F}\right) \text {. }\end{array}$ & Kerosene & 27 & 81 & 32 & $28.7 \pm 1.9$ \\
\hline 9 & 6 & $\begin{array}{l}\text { 60-percent relative humidity, room tem. } \\
\text { perature. }\end{array}$ & .....do. $0 . \ldots$ & 22 & 72 & 52 & $25.4 \pm 1.3$ \\
\hline 10 & 6 & Dried at $110^{\circ} \mathrm{C}\left(230^{\circ} \mathrm{F}\right)$ for 48 hours..... & $\ldots$ do............. & 22 & 72 & 29 & $27.6 \pm 1.7$ \\
\hline 11 & 6 & $\begin{array}{l}\text { Dried over } \mathrm{CaCl}_{2} \text { for } 36 \text { hours at } 26^{\circ} \mathrm{C} \\
\left(79^{\circ} \mathrm{F}\right) \text {. }\end{array}$ & do. $0^{0} \ldots \ldots$ & 62 & 144 & 33 & $29.5 \pm 1.9$ \\
\hline 12 & 6 & $\begin{array}{l}\text { Dried at } 110^{\circ} \mathrm{C}\left(230^{\circ} \mathrm{F}\right) \text {. Dipped in } \\
\text { parafin at } 80^{\circ} \mathrm{C}\left(176^{\circ} \mathrm{F}\right) \text {. }\end{array}$ & Paraffin costing & 22 & 72 & 25 & $33.8 \pm 1.8$ \\
\hline
\end{tabular}

- Limits given are for 95-percent confidence. See references [7, 8].

- Absolute ethyl alcohol denatured with about 5-percent absolute methyl.

- Water-free kerosene containing metallic sodium.

The strength of specimens dried at $110^{\circ} \mathrm{C}\left(230^{\circ} \mathrm{F}\right)$ and dipped in molten paraffin (test 12) was significantly greater than that resulting from any other treatment. The paraffin film was about $0.01 \mathrm{~mm}$ thick.

\section{EFFECT OF TEMPERATURE ON MODULUS OF RUPTURE}

In order to establish standard testing conditions, it was desired to determine the effect of temperature on the modulus of rupture of the frit fibers. Since humidity influences the strength, it was necessary to eliminate this variable. This was done by breaking the fibers under water-free kerosene after the specimens had been previously dried by storage for $36 \mathrm{hr}$ over $\mathrm{CaCl}_{2}$.

Tests 8 and 11 , made at $27^{\circ} \mathrm{C}\left(81^{\circ} \mathrm{F}\right)$ and $62^{\circ} \mathrm{C}\left(144^{\circ} \mathrm{F}\right)$, respectively (see table 2), show no significant difference in strength and indicate that temperature of itself does not appreciably influence the modulus of rupture of the frit fibers within the range of temperatures studied.

\section{VARIATION IN MODULUS OF RUPTURE WITH TYPE OF FRIT}

From the data presented in the previous sections, it is obvious that, to obtain reproducible results with modulus of rupture tests on fibers of enamel frit, it is essential to make the determinations under controlled humidity conditions. Inasmuch as determinations by the increasing-load tests could be carried out in about one-fourth of the 
time required for the sustained-load tests, and with fewer specimens for approximately the same percentage of error, this method was chosen for comparing the strengths of the frits. The data are summarized in table 3.

TABLE 3.-Modulus of rupture and modulus of elasticity of enamel-frit fibers

\begin{tabular}{|c|c|c|c|c|c|}
\hline \multirow{2}{*}{$\begin{array}{c}\text { Frit } \\
\text { num- } \\
\text { ber }\end{array}$} & \multirow[b]{2}{*}{ Type of enamel a } & \multicolumn{2}{|c|}{ Modulus of rupture b } & \multicolumn{2}{|c|}{ Modulus of elasticity } \\
\hline & & $\begin{array}{l}\text { Number } \\
\text { of speci- } \\
\text { mens }\end{array}$ & $\begin{array}{l}\text { A verage } \\
\text { value }\end{array}$ & $\begin{array}{l}\text { Number } \\
\text { of speci- } \\
\text { mens }\end{array}$ & $\begin{array}{l}\text { Average } \\
\text { value c }\end{array}$ \\
\hline $\begin{array}{r}1 \\
11 \\
25 \\
35 \\
6\end{array}$ & $\begin{array}{l}\text { Soft ground coat } \\
\text { Hard ground coat. } \\
\text { Ordinary cover coat. } \\
\text { Superopaque cover coat } \\
\text { Acid-resisting cover coat. }\end{array}$ & $\begin{array}{l}51 \\
52 \\
53 \\
54 \\
52\end{array}$ & $\begin{array}{r}\mathrm{kg} / \mathrm{mm}^{2} \\
18.0 \pm 1.5 \\
20.1 \pm 1.1 \\
24.6 \pm 1.6 \\
23.2 \pm 1.3 \\
24.8 \pm 1.6\end{array}$ & $\begin{array}{l}35 \\
78 \\
36 \\
30 \\
41\end{array}$ & $\begin{array}{l}\mathrm{kg} / \mathrm{mm}^{2} \\
8,250 \pm 70 \\
8,420 \pm 50 \\
8,010 \pm 110 \\
8,030 \pm 130 \\
8,470 \pm 130\end{array}$ \\
\hline $\begin{array}{l}65 \\
85 \\
72\end{array}$ & $\begin{array}{l}\text { Leadless dry process } \\
\text { Lead-bearing dry process } \\
\text { High lead, cast iron d }\end{array}$ & $\begin{array}{l}54 \\
54\end{array}$ & $\begin{array}{l}16.9 \pm 1.0 \\
19.0 \pm 1.0 \\
-\end{array}$ & $\begin{array}{r}36 \\
54 \\
8\end{array}$ & $\begin{array}{l}8,100 \pm 80 \\
7,620 \pm 110 \\
6,120 \pm 470\end{array}$ \\
\hline
\end{tabular}

a Wet process, except where otherwise stated.

b Modulus-of-rupture values are for annealed specimens broken in air at $70^{\circ} \mathrm{F}$ and 60 -percent relative humidity ( 65 percent for frits 1 and 6 ) by increasing-load test, after at least 20 hours of storage under the test conditions.

- Limits given are for 95-percent confidence. See references 7 and 8.

d Because of peculiar consistency of high-lead cast-iron enamel, fibers were formed only with difficuity and were covered with surface imperfections.

The data obtained at $21^{\circ} \mathrm{C}\left(70^{\circ} \mathrm{F}\right)$ and 60 - to 65 -percent relative humidity indicate that the three sheet-iron cover coats $(6,25$, and 35$)$ were significantly stronger than both the sheet-iron ground coats (1 and 11) and the cast-iron enamels (65 and 85). "The "hard" ground coat 11 was significantly stronger than the "soft" ground coat 1 . No data were obtained on the high-lead cast-iron enamel 72, since no fibers satisfactory for this test could be drawn from the molten frit.

\section{DISCUSSION OF RESULTS}

The large difference in average modulus of rupture obtained with the sustained-load and with the increasing-load tests, indicated in table 1, could be caused in some degree by the greater moisture content of the air for the same relative humidity at the higher temperature used in the sustained-load tests. However, the large difference in apparent strength under the two conditions of test conforms with well-known experience on a number of other materials, and has been reported previously for enamel frits [5].

From the lower modulus-of-rupture values obtained in sustained loading, it may be concluded that vitreous enamel should withstand briefly applied stresses involving no plastic flow of the metal, better than it should withstand stresses of the same magnitude which are sustained over a considerable period of time. Delayed chipping may well be a manifestation of delayed fracture under constant stress. Assuming that a sustained tensile stress is introduced at some edge or corner of an enamel shape during processing or assembling, it is conceivable that the ware might require several hours or even days to chip, depending on the magnitude of the stress. In a border-line case the chipping might not occur until a period of high atmospheric humidity prevailed. Likewise, in a border-line case, humidity might 
determine whether a given briefly applied stress would cause failure or not.

The fact that humidity has a significant effect on the modulus of rupture of enamel is not surprising in view of results obtained in some previous investigations of other ceramic products. A. C. Harrison [9], describing a falling-sand abrasion test for whiteware glazes, reported, in 1927 , as follows:

"Early in the investigation unaccountable variations were noted in the resistance of the same glazes upon testing them on different days. Finally, a series of tests extending over a period of two weeks were made on the same brand of hotel chinaware. Contemporary records of atmospheric conditions showed the resistance of the glaze to be proportional to the percent relative humidity of the atmosphere ***."

Milligan [10], in 1929, reported that scratched-glass bars that would sustain transverse loads for several days without failure in dry air would fail in from 1 to 30 hours under the same loads in air saturated with water vapor. Schurkow [11] worked with fused-quartz filaments from 2 to 10 microns in diameter and found that the tensile strength was on the order of 50 percent greater when tested in air dried with $\mathrm{CaCl}_{2}$ than when tested in "room air." He found no difference between the strength of fused-quartz filaments in "room air" and the strength under water. In the present study, however, the strength of enamel frit 6 was found to be almost 30 percent greater in air at 65 -percent relative humidity than when immersed in water (see tests 5 and 6 , table 2). The strength in air at 98-percent relative humidity was intermediate (see table 1). Frit 1 was somewhat stronger in air at 65-percent relative humidity than it was in air at 98-percent relative humidity, or in water, but the differences in this case were not statistically significant.

Schurkow also found the strength of fused-quartz fibers which had been preheated in a vacuum, and which were tested in a vacuum, to be several times greater than the strength of similar fibers tested in "room air" or in water. Some of his results were later confirmed by Reinkober [12].

The large decreases in strength noted by Griffith [13] on aged fibers of soda-lime-silica glass as compared with freshly drawn specimens might possibly have been caused by the effect of atmospheric moisture.

Grebenchikov, who is quoted by Jurkov [14], explains the effect of humidity and also the effect of various liquids on the strength of silicate glasses by postulating the presence of a thin colloidal film (silica gel) on the surface of the specimen, which swells or contracts, depending on the conditions to which the specimen is exposed. The film is assumed to be present also in surface cracks or discontinuities and to produce a concentration of stress at these points, which varies with the physical state of the gel. Thus, in the presence of an increased concentration of moisture, the gel would swell, causing an increase in the localized stresses at the flaw so that less externally applied force would be required to cause failure. When moved from a damp to a dry atmosphere, the gel would contract and relieve some of the localized stress, thus requiring more applied load to cause failure.

Even though the silica gel postulated by Grebenchikov were not present, specimens immersed in water would tend to draw the water into any cracks or surface flaws through capillary attraction. The 
air entrapped in a flaw would be compressed by the advancing water and thereby increase the localized stresses. If such a mechanism is effective, it should operate for any liquid which wets the specimen, and its effect should be a function of the surface tension of the liquid. The same mechanism might conceivably operate in the open air if the amount of moisture absorbed in the flaws increased with increasing humidity. It is the authors' opinion, however, that this explanation accounts, at most, for only a part of the observed phenomena, it being particularly weak in explaining the atmospheric-humidity effects.

Another possible explanation is that the water which is dissolved in the glass [15] (or enamel), and which might be expected to vary in concentration with the humidity of the atmosphere, actually reduces the strength of the material to an extent dependent upon the concentration of the dissolved water. For such changes in dissolved water to be effective, it would be sufficient if the moisture content changed in the surface layer only, since the maximum stress and the beginning of failure occur at the surface.

\section{TORSION TESTS ON ENAMELED-IRON SPECIMENS}

Having found that variation in atmospheric humidity affects the modulus of rupture of enamel-frit fibers, it was desired to determine whether or not it also affects the resistance to chipping of enamel applied to metal specimens. For this purpose, the angular specimens previously described under section II were enameled and tested.

\section{METHOD OF TESTING}

The specimens were tested by inserting one end $11 / 2$ in. $(3.8 \mathrm{~cm})$ into a fixed right-angle clamp, and the opposite end $1 \frac{1}{2}$ in. into a free right-angle clamp having a horizontal lever arm with pointer attached. Load was applied at the end of the lever at a uniform rate to give an angular deflection of about $2^{\circ}$ per min. The angle of twist required to cause the first chip at any point along the 4 -in. $(10 \mathrm{~cm})$ cover-coated apex of the specimen was observed. ${ }^{5}$ The thickness of the enamel immediately adjacent to the chip was measured to \pm 0.0002 in. $(0.005 \mathrm{~mm})$ with a Brenner magnetic thickness gage [16].

\section{EFFECT OF HUMIDITY ON RESISTANCE TO CHIPPING BY TORSION}

Determinations were made at $70^{\circ} \mathrm{F}$ in atmospheres of 35 - and 98-percent relative humidity, after prior storage under the conditions of test for not less than $24 \mathrm{hr}$. Some of the specimens were dipped in molten paraffin immediately after firing and before completely cooling to room temperature. These were stored and tested at 98-percent relative humidity.

Figure 3 shows the results obtained. Each point in this figure represents a different specimen. If comparisons are made at a thickness of 15 mils $(0.38 \mathrm{~mm})$, the angle required to cause chipping at 35 percent humidity is about 15 percent greater than at 98 percent. The

This test was developed in connection with the work of Poul I. Smith for the Porcelain Enamel Institute Research Associateship at the National Bureau of Standards. 
paraffin treatment, which presumably kept the specimens dry even though the atmosphere was at 98-percent relative humidity when they were tested, increased the resistance about 30 percent. The

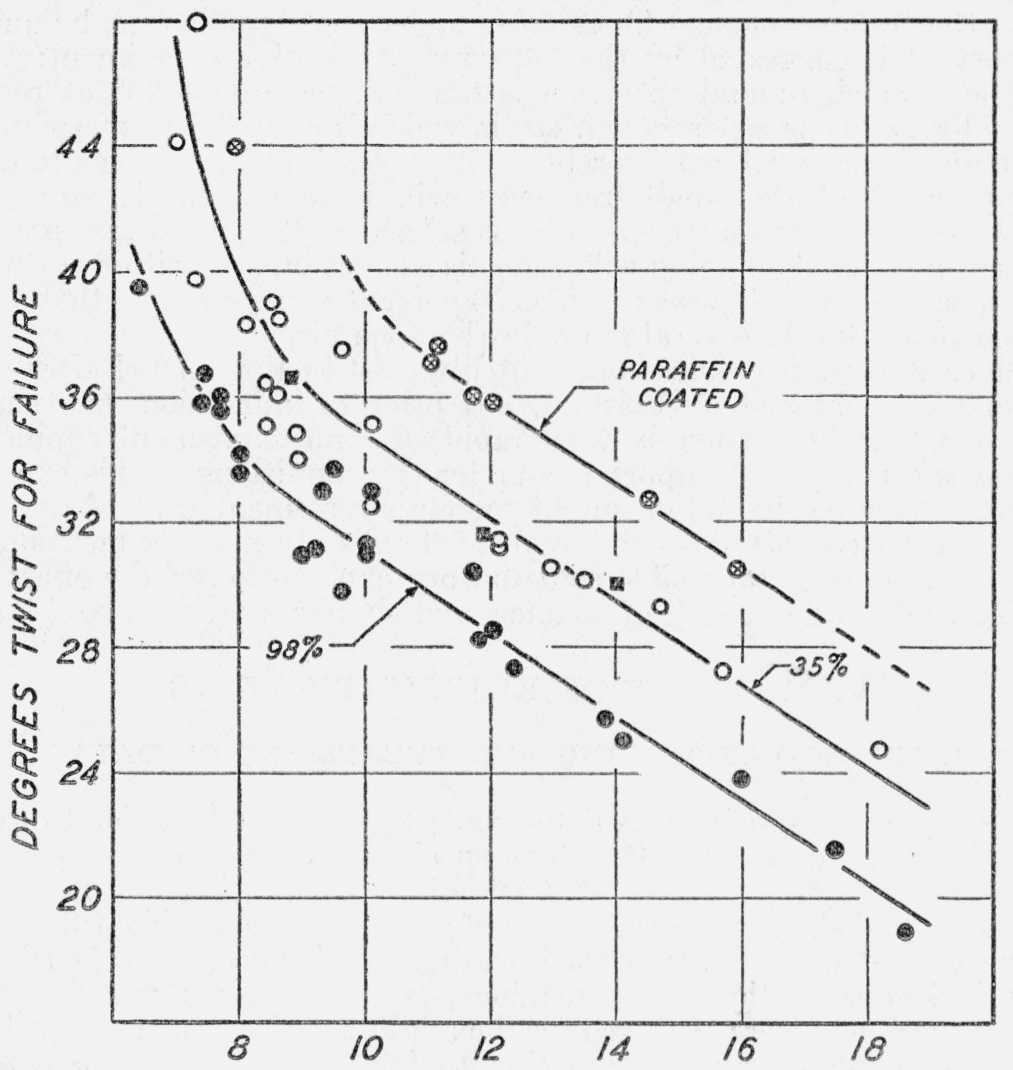

THICKNESS OF ENAMEL IN MILS

FIGURE 3.-Angle of twist required to cause chipping of enameled-iron specimens, plotted against thickness of enamel.

The three curves are for tests made at 98-percent and at 35-percent relative humidity, respectively, on untreated specimens and on specimens given a moisture-repellent coating of paraffin before completely cooling after firing.

three solid squares on the 35-percent humidity curve represent specimens stored $72 \mathrm{hr}$ at 98 -percent humidity and then returned to 35 percent relative humidity, stored $24 \mathrm{hr}$, and tested.

\section{DISCUSSION OF RESULTS}

It is evident that a decrease in humidity increases the chipping resistance of enameled-iron specimens in torsion, a result which is in agreement with the modulus-of-rupture tests on frit fibers.

The data represented by the squares in figure 3 show that under the conditions of test the effect of varying humidity is reversible; that is, the lowering of strength at 98-percent relative humidity did not persist after the specimens were returned to an atmosphere of 35- 
percent relative humidity. This reversibility is in accord with the findings of Milligan [10] and Anderegg [17] that glass weakened by immersion in water regained its strength when dried.

That the mechanism of capillary attraction discussed in connection with the tests on enamel fibers may, under some conditions, be quite important is suggested by the following qualitative experiment:

The enameled-metal specimen is first twisted about $90^{\circ}$ at room humidity, causing a permanent strain which is of sufficient magnitude to chip the enamel considerably. In several hours the continued chipping off of the small fragments will have practically stopped. However, when the same specimen is subsequently placed in a pan of water, additional chipping will immediately set in, and within $15 \mathrm{~min}$ the specimen may show as much as 50 percent more chipping than had taken place during several hours in the open air.

Since numerous crevices undoubtedly exist in the enamel after the specimen is chipped by twisting, but prior to immersion, and since the effect of immersion is very rapid, the mechanism of capillary attraction may be of importance under the conditions of this experiment. Even so, its action might merely supplement that of the gel film postulated by Grebenchikov or of the dissolved water mentioned by the authors as a possible contributory explanation of the effect of moisture on the strength of enamels and similar materials.

\section{MODULUS OF ELASTICITY TESTS}

\section{METHOD OF TESTING AND TREATMENT OF DATA}

Modulus of elasticity was determined by a method similar to that used in a previous study [5]. The specimens were measured with a dial micrometer to the nearest $0.005 \mathrm{~mm}$. A small flag consisting of a gummed label was fixed to one end of each specimen for identification purposes and also to indicate the least diameter in specimens of slightly elliptical cross section. Ten readings, evenly spaced along the axis of the specimen, were averaged for the minimum diameter and another 10 were taken at right angles thereto for the maximum diameter. No specimens were used with maximum deviations from the average greater than $0.045 \mathrm{~mm}$. During a test a micrometer microscope, which could be read to $0.005 \mathrm{~mm}$, was mounted to focus on the midspan of the enamel fiber. The fiber rested on fixed knife-edges separated by a span of $91.23 \mathrm{~mm}$. A small aluminum pan, giving a tare of $5 \mathrm{~g}$, was suspended by a fine wire from the midpoint of the span. The load, either 5 or $10 \mathrm{~g}$, depending on the diameter of the specimen, was applied by placing calibrated weights on the pan. By rotating the specimen through an angle of $90^{\circ}$ after each deflection reading, four measurements were obtained for each fiber, and the average of the four was used for computing the modulus.

The data were treated statistically by the procedure used in the increasing-load tests for strength.

\section{EFFECT OF HUMIDITX ON MODULUS OF ELASTICITY}

Several tests were made to determine the effect of humidity on the modulus of elasticity of enamel-frit fibers. Frits 1 and 65 were chosen for study, and determinations were made at $22^{\circ} \mathrm{C}\left(72^{\circ} \mathrm{F}\right)$ in 
atmospheres at 98- and 50-percent relative humidities, respectively. The data showed no change in Young's modulus, and therefore humidity was not controlled for the tests reported in table 3.

\section{VARIATION IN YOUNG'S MODULUS WITH TYPE OF FRIT}

Table 3 includes a summary of the data obtained on the eight frits. Tests for differences in the averages showed Young's modulus of the "soft" ground-coat frit 1 to be significantly lower than that for the "hard" ground-coat frit 11. Cover coats 25, 35, and 65 had lower moduli than the acid-resisting cover-coat frit 6 . The leadbearing enamels, frits 85 and 72 , have lower moduli than the other types, that of the high-lead composition (frit 72) being lowest.

Figure 4 is a frequency histogram prepared from the data on frit 11. A total of 78 specimens of this frit were tested to establish whether or not the determined values were approximately normally distributed. Visual examination of figure 4 suggests an approximately normal distribution, and calculated skewness is only +0.10 [7].

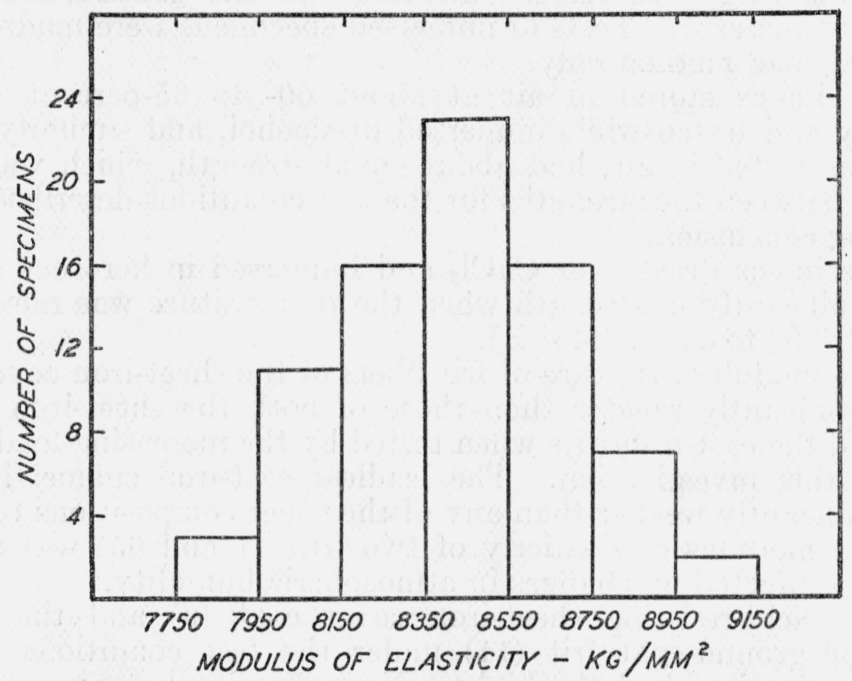

FIGURe 4.-Frequency histogram showing distribution of 78 modulus-of-elasticity determinations with ground-coat frit 11.

\section{DISCUSSION OF RESULTS}

The average moduli in table 3 are of about the same order of magnitude as those reported previously by Harrison, Shelton, and Wadleigh [5], and are about 8 percent higher on the average than the results given by Stong [18] for a special bulb-glass composition. The values approximating $4,000 \mathrm{~kg} / \mathrm{mm}^{2}$ reported by Anderegg [17] for glass fibers are in fair agreement with those reported by Reinkober [12]. However, subsequent results by Jurkov [14], using more precise methods of measuring deflections, did not agree with Reinkober's data. The average modulus given by Jurkov is $8,000 \mathrm{~kg} / \mathrm{mm}^{2}$. The results of Fetterolf and Parmelee [19] are considerably lower, approxi- 
mating 5,000 to $6,000 \mathrm{~kg} / \mathrm{mm}^{2}$. Their results, however, were obtained on rods of much larger cross section loaded as cantilevers.

\section{CONCLUSIONS}

1. The modulus of rupture of enamel-frit fibers increased with decreasing atmospheric humidity. The maximum change observed was in the sustained-load test, in which a "soft" sheet-iron ground-coat frit (1) was 53 percent stronger at 56-percent relative humidity than at 90 percent, the temperature being $36^{\circ} \mathrm{C}\left(97^{\circ} \mathrm{F}\right)$. Under the same conditions an acid-resisting sheet-iron frit (6) was 15 percent stronger at the lower humidity.

2 . In the increasing-load test the gains in strength of these frits were 8 and 22 percent, respectively, when the relative humidity was decreased from 98 to 35 percent at $21^{\circ} \mathrm{C}\left(70^{\circ} \mathrm{F}\right)$.

3 . The modulus of rupture of enamel-frit fibers was substantially greater when they were dried over $\mathrm{CaCl}_{2}$ and immersed in water-free kerosene than when they were immersed in water, the acid-resisting frit (6) showing a 49-percent increase and the ground coat (1) a 30-percent increase. Tests of immersed specimens were made by the increasing-load method only.

4. Specimens stored in air at about 60- to 65-percent relative humidity and tested while immersed in alcohol, and similarly stored specimens tested in air, had about equal strength, which was intermediate between the strengths for the two conditions described in the preceding conclusion.

5. Specimens dried over $\mathrm{CaCl}_{2}$ and immersed in kerosene did not vary significantly in strength when the temperature was raised from $27^{\circ} \mathrm{C}\left(81^{\circ} \mathrm{F}\right)$ to $62^{\circ} \mathrm{C}\left(144^{\circ} \mathrm{F}\right)$.

6 . The moduli of rupture of frit fibers of the sheet-iron cover coats were significantly greater than those of both the sheet-iron ground coats and the cast-iron frits when tested by the increasing-load test as used in this investigation. The leadless cast-iron enamel frit (65) was significantly weaker than any of the other compositions tested.

7. The modulus of elasticity of two frits (1 and 65) was not significantly affected by changes in atmospheric humidity.

8. The acid-resisting sheet-iron cover coat (6) and the "hard" sheet-iron ground-coat frit (11) under the test conditions used in this investigation, had the highest Young's modulus, approximately $8,400 \mathrm{~kg} / \mathrm{mm}^{2}$. The other sheet-iron cover coats and the leadless cast-iron enamel gave average moduli of about $8,000 \mathrm{~kg} / \mathrm{mm}^{2}$, while the lead-bearing cast-iron enamels were significantly lower, the high-lead composition being lowest.

9. When applied to 20-gage metal, the resistance of an acidresisting enamel (6) to chipping in torsion increased about 15 percent with a decrease in relative humidity from 98 to 35 percent. A thin paraffin coating over the enamel surface, applied before the specimens were quite cool after firing, increased the resistance of these specimens to chipping in torsion by about 30 percent, even though the surrounding air was at 98 -percent relative humidity. 


\section{REFERENCES}

[1] W. N. Harrison, R. E. Stephens, and S. M. Shelton, J. Research NBS 20, 39 (1938) RP1063.

[2] W. N. Harrison and D. G. Moore, J. Research NBS 21, 337 (1938) RP1133.

[3] W. N. Harrison and B. J. Sweo, BS J. Research 10, 189 (1933) RP524.

[4] L. V. Black, Bul. Am. Ceram. Soc. 15, 274 (1936).

[5] W. N. Harrison, S. M. Shelton, and W. H. Wadleigh, J. Am. Ceram. Soc. 18, 100 (1935).

[6] C. I. Bliss, Ann. Applied Biol. 22, 134 (1935).

[7] Am. Soc. Testing Materials Manual on Presentation of Data (March 1937).

[8] R. A. Fisher, Statistical Methods for Research Workers (Oliver and Boyd, London; 1936 edition).

[9] A. C. Harrison, J. Am. Ceram. Soc. 10, 77 (1927).

[10] L. H. Milligan, J. Soc. Glass Tech. 13, 351 (1929).

[11] S. Schurkow, Physik. Z. Sowjetunion 1, 123 (1932).

[12] O. Reinkober, Physik. Z. 38, 112 (1937).

[13] A. A. Griffith, Phil. Trans. Roy. Soc. (London) [A] 221, 163 (1920).

[14] S. Jurkov, Tech. Phys. USSR 1, 392 (1935).

[15] C. Hahner, G. Q. Voigt, and A. N. Finn, J. Research NBS 19, 95 (1937) RP 1014.

[16] A. Brenner, J. Research NBS 20, 357 (1938) RP1081.

[17] F. O. Anderegg, Ind. Eng. Chem. 31, 290 (1939).

[18] G. A. Stong, J. Am. Ceram. Soc. 20, 16 (1937).

[19] L. D. Fetterolf and C. W. Parmelee, J. Am. Ceram. Soc. 12, 3 (1929).

Washington, July 14, 1939. 